\title{
A relação entre pragmática, semântica e gramática*
}

\author{
Hardarik Blühdorn \\ Universidade de São Paulo
}

\section{Abstract}

The present paper examines the relationship between pragmatics, semantics and grammar as subdisciplines of linguistics from three different perspectives. The first section gives a historical survey of their development during the 20th century and classifies linguistic schools according to their interest in different fields of research. The second part presents a systematic model of the field of objects to be investigated by linguistics, aiming at a more precise delimitation of its subdisciplines. Finally, in the third section, the division of labour between pragmatics, semantics and grammar is discussed in the light of the concrete example of verb valence. 


\section{INTRODUÇÃO}

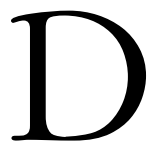

iscutir a arquitetura da lingüística estava muito em voga nos anos setenta. Mas como tal discussão em si não levou a resultados suficientemente concretos, muitos lingüistas, decepcionados, a abandonaram. Nos anos oitenta, os pesquisadores estavam interessados principalmente em estudos empíricos, considerando-se reflexões teóricas e estratégicas um tanto ultrapassadas. Nos anos noventa, todavia, percebe-se um interesse renovado em abordagens teóricas, pois cada vez mais a lingüística se vê diante da necessidade de integrar seus resultados empíricos. De certa maneira, a situação parece assemelhar-se à do início do século, quando o esforço positivista da escola neogramática se esgotou e cedeu lugar aos primeiros trabalhos estruturalistas.

A seguir, examinarei a relação entre três subdisciplinas da lingüística, a saber a pragmática, a semântica e a gramática, sob três perspectivas diferentes. Em primeiro lugar, traçarei uma visão histórica de seu desenvolvimento durante o século XX; a seguir, apresentarei um modelo sistemático do universo de objetos pesqui-sados pela lingüística, a busca de uma delimitação mais precisa de suas subdisciplinas; e, por último, discutirei, a partir de um exemplo concreto, a divisão de trabalho entre elas.

\section{VISÃO HISTÓRICA}

\subsection{Semiótica: Peirce}

Uma opinião corrente entre muitos autores do século XX considera a lingüística subdisciplina da semiótica. Tal categorização, porém, não é válida a priori. Outros modelos compreendem a lingüística como subdisciplina da filosofia, da sociologia, da 
psicologia, ou até da matemática. Entre os autores que vêem a lingüística como parte da semiótica, o valor que atribuem a essa classificação difere muito; ademais, nem todos entendem por semiótica a mesma coisa.

A semiótica, como foi concebida pelo filósofo norte-americano Charles S. Peirce (1839-1914) (cf. Peirce 1931-1958; Nöth 1995:63 ss.), no terceiro terço do século XIX, é a ciência dos signos no sentido mais abrangente possível. Ela deve ser entendida como uma forma de filosofia, que incorpora a sociologia, a psicologia e a matemática, entre outras disciplinas. Segundo esta concepção, todo conhecimento disponível aos seres humanos tem a forma de signos, internos ou externos aos seus corpos. O mundo inteiro compõe-se de signos, e a ciência dos signos, portanto, é a ciência superior a todas as outras disciplinas (posição denominada de pansemiotismo). Os signos lingüísticos, os objetos da lingüística, constituem apenas um conjunto parcial dos objetos da semiótica. Mas sejam eles considerados objetos sociais, psíquicos ou matemáticos, em todos os casos eles seriam, segundo PeIrce, ao mesmo tempo objetos semióticos.

A filosofia de Peirce não pode ser considerada lingüística. PeIrCE estava interessado em questões bem mais teóricas e genéricas, em lógica formal, matemática, teoria do conhecimento. Mas sua filosofia, que ele mesmo denominou de pragmatismo (PeIRCE 1983: 162 ss.; cf. também Oenter 1981: 41 ss.), pode ser entendida como antecessora da pragmática. Tal interpretação indicaria que a pragmática como disciplina parcial da lingüística seria superior às outras disciplinas parciais, assim como a semiótica é superior a todas as outras ciências.

\subsection{Morris}

Um outro semioticista americano importante, cuja obra, partindo de algumas idéias de PEIRCE, se dedica mais a questões lingüísticas propriamente ditas, foi Charles W. Morris (1901-1979). Morris, em seu artigo de 1938, Foundations of the theory of signs, divide a semiótica geral em três subdisciplinas: a sintática, que se ocupa das 
relações entre signos e outros signos, a semântica, que se interessa pelas rela-ções entre signos e seus designados, e a pragmática, que examina as relações entre signos e seus usuários.

Tal divisão pode ser aplicada a qualquer ciência cujo objeto seja um sistema de signos. Aplicando-a à lingüística, como ciência da linguagem natural, obtemos as três subdisciplinas da sintática, semân-tica e pragmática lingüística. Na época em que MorRis escreveu seu artigo, apenas a primeira estava suficientemente desenvolvida para já aparecer como um campo delimitado de conhecimento. A semântica e a pragmática lingüística ainda aguardavam seu desbravamento como áreas de pesquisa científica.

Sintática lingüística, no sentido de Morris, significa gramática. É interessante que Morris usou o termo sintática numa década em que a sintaxe como campo de pesquisa na lingüística quase não existia. Nos anos trinta de nosso século, os assuntos en vogue eram a fonologia e a morfologia. A assim chamada gramática tradicional, ou seja, a gramática didática pós-latina, baseou-se principalmente na classificação de tipos de palavras. A sintaxe foi entendida como a arte de conectar palavras a fim de formar orações. Uma gramática que se baseasse na unidade da própria oração, como a gramática gerativa de Сномsку (1965, entre outros), também aguardava, ainda, seu desbravamento.

Percebemos, então, que a divisão da semiótica dada por MorRIS foi bastante profética quanto à lingüística de sua época, em que ainda não existiam nem a sintaxe científica, nem a semântica, nem a pragmática da língua natural. Mas verificamos também que, hoje em dia, o termo gramática, em vez de sintática, parece um pouco mais apropriado, pois gramática abrange dois tipos de relações entre signos: relações in praesentia (cf. SAussure 1916: 143), ou seja, sintagmáticas, que se mostram mais obviamente nos campos da sintaxe e da formação de textos, e relações in absentia (ib.), ou seja, paradigmáticas, que aparecem mais obviamente nos campos da morfologia e lexicologia (p.ex., nos paradigmas da flexão e da formação de palavras). 


\subsection{Bühler}

Um terceiro autor importante a ser mencionado aqui é o psicólogo alemão Karl BüHLER (1879-1963) que, em sua obra principal Sprachtheorie. Die Darstellungsfunktion der Sprache (Teoria da linguagem. A função representativa da língua) de 1934, desenvolveu os fundamentos de uma pragmática e semântica funcional. BüHLER é o autor de um famoso modelo da comunicação, denominado com o termo grego modelo organon, que mostra o signo no meio de três grandezas: o emissor que o produz e emite, o receptor que o percebe e interpreta, e os objetos e estados de coisas que o falante pretende comunicar.

A partir desse modelo, BüHLER define três funções comunicativas do signo que, aplicadas ao sistema de signos da língua natural, ele interpreta como as três funções da linguagem (Funktionen der Sprache). A primeira função liga o signo ao emissor (Sender), cujo estado atual (humor, sentimentos, intenções de comunicar, etc.) ele deixa transparecer. O signo, segundo BüHLER, é um sintoma do emissor, e esta função ele denomina de expressão ( $A u s d r u c k$ ). A segunda função liga o signo ao receptor (Empfänger), cujo comportamento ele orienta. O signo, neste sentido, é um sinal ao receptor, e a função é chamada de apelo (Appell). A terceira função liga o signo aos objetos e estados de coisas que ele designa (Gegenstände und Sachverhalte). Neste sentido, é um símbolo, e a função é chamada de representação (Darstellung).

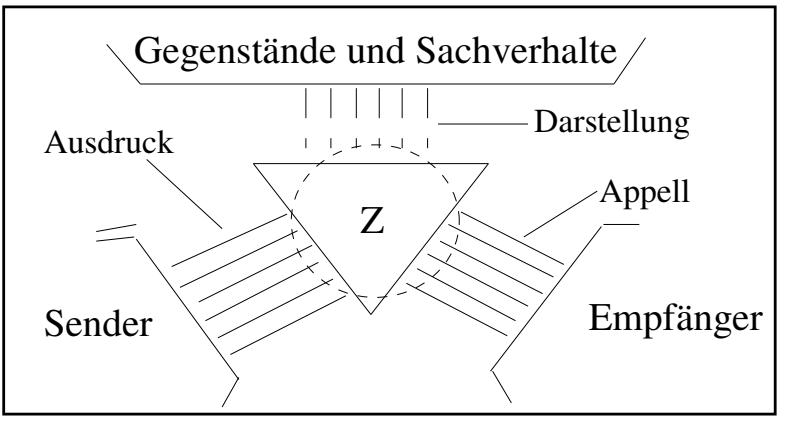

FIGURA 1: O modelo organon de BüHLER (1934-1982: 28) 
O modelo organon pode ser considerado um modelo do objeto da pragmática. Na obra de BüHLER, ele forma um dos fundamentos teóricos para a discussão de questões semânticas, por exemplo, para a distinção entre o assim chamado campo simbólico (Symbolfeld) e o campo indexical (Zeigfeld) da linguagem. Com esses termos, BüHLER discrimina dois tipos de palavras, cujos valores semânticos considera diametralmente opostos, a saber, as palavras-denominadores (Nennwörter), que funcionam como símbolos, representando seus designados, e as palavras-indicadores (Zeigwörter), que funcionam como sinais, orientando seus receptores (cf. BüHLER 1934-1982: 149 ss.). O primeiro grupo compõe-se da grande maioria das palavras e é exemplificado prototipicamente pelos substantivos, enquanto o segundo consiste do conjunto relativamente pequeno das palavras dêiticas, prototipicamente exemplificadas pelos determinadores, como o artigo definido, os pronomes pessoais como eu e por alguns advérbios como aqui e agora.

Com base em seu modelo pragmático e em sua concepção da semântica, BüHLER discute, na terceira parte do livro (ib.: 256 ss.), algumas questões da gramática, mais especificamente da sintaxe. Os capítulos pertinentes, mesmo sendo de caráter relativamente genérico, podem ser considerados prospectivos sob alguns aspectos. Encontram-se neles reflexões sobre verbos e seus complementos e sobre a semântica dos casos nas línguas indo-européias, que se assemelham a idéias posteriormente formuladas na teoria de valências de Lucien Tesnière (1959) e Gerhard Helbig (1965, 1966, 1992, entre outros) e na teoria de casos de Charles J. Fillmore (1968, entre outros). Aparecem, também, comentários sobre pronomes e determi-nadores, especialmente sob o aspecto da anáfora, que ultrapassam o limite da oração e antecipam conceitos da lingüística textual.

Nesse sentido, portanto, a obra de BüHLER é importante, pois desenvolve uma visão generalizada da lingüística como subdisciplina da semiótica. No seu modelo, a pragmática é apresentada como o fundamento sobre o qual se estabelece a semântica, e as duas servem de base para a gramática. Entre as três, a pragmática é a mais detalhadamente tratada. 


\subsection{Estruturalismo anglo-americano}

A lingüística anglo-americana do mainstream estruturalista e gerativista dos anos cinqüenta e sessenta concebeu a relação de suas subdisciplinas de maneira bastante diferente. Os estruturalistas angloamericanos ocuparam-se principalmente dos aspectos formais dos sistemas de signos, ou seja, da gramática das línguas naturais. Fonologia, morfologia e sintaxe foram vistas como o fundamento da lingüística. Na obra Language, de Leonard Bloomfield (1933: 167), a semântica ficou, explicitamente, excluída. Quando passou a ser aceita, nos anos cinqüenta, ela foi acrescentada como mais uma camada a uma arquitetura estratal. A partir daí, lingüística significava fonologia, morfologia, sintaxe e semântica. Até hoje, essas quatro subdisciplinas muitas vezes são reunidas como integrantes da gramática enquanto lingüística nuclear (ou microlinguistics, para usar o termo de John Lyons, 1981: 36) (cf. p.ex. Perini 1996: 49 s.).

Quando foi inaugurada, principalmente pelos trabalhos de John L. Austin (1962), John R. Searle (1969, entre outros) e H. Paul Grice (1975, entre outros) nos anos sessenta e setenta, a pragmática lingüística anglo-americana, ela também começou a ser incorporada à mesma arquitetura estratal. Gramáticos gerativistas tentaram modelar o componente pragmático como sistema de hipersentenças performativas, achando que poderiam analisar ilocuções e perlocuções basicamente com as mesmas ferramentas que foram inventadas para analisar sintagmas nominais e verbais (Ross 1968-1970, SADOCK 1969; cf. também Wunderlich 1971, AвRAHAm 1972). Tal postura impediu, por algum tempo, que a pragmática fosse concebida como mais do que a teoria dos atos de fala e das implicaturas conversacionais.

A partir da segunda metade dos anos setenta, porém, a pragmática começou a se abrir paulatinamente para questões antes não discutidas como, por exemplo, a expressão de polidez e gentileza. Geoffrey N. LEech, em seu livro Principles of Pragmatics, de 1983, postulou uma diferença fundamental entre gramática e pragmática, tendo a primeira como objeto um sistema de regras, enquanto a segunda se ocuparia meramente de princípios. Sob este ponto de 
vista, uma regra é entendida como algo categórico e geral, a ser aplicado ou não a um determinado caso, enquanto um princípio permite aplicações graduais e segundo critérios individuais.

Conseqüentemente, as escolas formais rígidas como a lingüística gerativa excluíram a pragmática novamente da lingüística stricto sensu. Ganhou importância a visão modular da cognição humana, segundo a qual a gramática constitui um sistema fechado, parcialmente inato e universal, enquanto a comunicação e seus princípios são determinados pela tradição de cada sociedade e têm que ser inteiramente aprendidos (cf. Сномsкy 1980; também Perini 1996: 241 ss.).

\subsection{Semântica}

Quanto à semântica, assistimos hoje à discussão entre aqueles que querem mantê-la, ao menos em parte, dentro de uma lingüística concebida como gramática, e aqueles que a separam cada vez mais decisivamente da gramática. O lingüista alemão Manfred BIERwisch desenvolveu, em vários artigos que publicou na primeira metade dos anos oitenta, o modelo de uma semântica de duas camadas (cf. Bierwisch 1982, 1983 a, 1983 b, entre outros). A estrutura semântica propriamente dita, ou seja, na terminologia de Lyons (cf. 1977: 174 ss.), as denotações e os sentidos dos elementos do léxico, ele subsume ao sistema lingüístico gramatical. A estrutura conceitual, por outro lado, ou seja, nosso conhecimento do mundo por meio do qual concretizamos os significados das palavras em referências, BiERWISCH exclui do sistema lingüístico. Segundo a visão modular da cognição, tal estrutura pode ser vista como parte de um módulo particu-larmente semântico ou como parte de um módulo semânticopragmático.

Uma outra lingüista alemã, Monika Schwarz (cf. 1992 b: 98 ss.), sugeriu o modelo de uma semântica de três camadas, que serve como vínculo entre gramática e pragmática. Ela se apóia em pesquisas neuro-psicológicas sobre a arquitetura da memória humana, postulando que a primeira camada semântica seria constituída pelas 
representações dos significados lexicais na memória de longa duração; a segunda seria constituída pelas representações de tais unidades, ativadas como significados atuais na memória de processamento em situações concretas de comunicação; e a terceira seria constituída pelas referências ao mundo externo por meio de elementos lingüísticos. A primeira camada seria mais intimamente ligada à gramática, a terceira à pragmática, e a segunda seria o local da mediação entre as duas.

\subsection{Ciência cognitiva}

Antes de terminar a abordagem histórica, quero mencionar, ainda, Dan SPERBER e Deirdre WiLSON, dois lingüistas que trabalham na França e na Inglaterra, com seu livro Relevance. Communication and Cognition, de 1986, e mais um lingüista alemão, Hans STroHnER, que publicou, em 1990, um livro intitulado Textverstehen. Kognitive und kommunikative Grundlagen der Sprachverarbeitung (Compreensão de textos. Fundamentos cognitivos e comunicativos do processamento lingüístico). Tanto Sperber e WiLson quanto STrohner são representantes da assim chamada ciência cognitiva, uma disciplina nova que reúne lingüistas, filósofos, psicólogos, matemáticos e pesquisadores da informática, visando à integração dos resultados empíricos e teóricos obtidos em todos esses ramos de conhecimento.

Os dois livros são tentativas de desenvolver uma visão da lingüística, na qual gramática, semântica e pragmática valem como subdisciplinas legítimas, com a pragmática em ambos os casos na função de ambiente em que as outras duas se situam. SPERBER e WiLSON partem de uma pragmática radical voltada à questão de como lingüística e teoria literária podem ser reconciliadas. Como componente gramatical, eles aceitam, em princípio, uma gramática gerativa, mas sem a noção pré-concebida de que ela seria o campo privilegiado de pesquisa da lingüística. A contribuição original de SPERBER e WILSON é o princípio de relevância postulado por eles, o qual seria um 
princípio cognitivo muito geral, que rege toda comunicação - desde conversas cotidianas até a literatura mais sofisticada - e as atividades cognitivas nela envolvidas. Com este princípio, os autores explicam uma série de fenômenos comunicativos como implicaturas, metáforas e ironia, entre outros.

STROHNER, por outro lado, parte da teoria dos sistemas e da teoria da informação. Ele concebe a comunicação como um sistema complexo que engloba, entre outros, os comunicadores e, com eles, o processamento cognitivo de textos que se desenrola em seus cérebros. Quanto à comunicação e à cognição, seu modelo, de certa forma, lembra os clássicos da semiótica BüHLER e MorRis (o primeiro também citado por STROHNER; cf. 1990: 11, 50). Os modelos que estes estabeleceram quase a priori parecem receber, 50 anos mais tarde, um fundamento novo em conformidade com dados empíricos que, na época, estavam longe de ser conhecidos. Quanto à estrutura formal dos signos lingüísticos, porém, STROHNER ainda tem pouco a dizer - o que torna provável que a história da lingüística ainda não tenha chegado ao seu ponto final.

\subsection{Escolas lingüísticas}

Em resumo, os elementos das línguas naturais podem ser considerados sob três aspectos funcionais: primeiro, em suas relações com outros elementos lingüísticos (o aspecto estrutural da linguagem, já mencionado por MorRis sob o termo sintática); segundo, em suas relações com o sistema de processamento de dados do ser humano (o aspecto cognitivo da linguagem, já mencionado por Peirce e, depois, entre outros, por Sperber \& Wilson e por Strohner); e terceiro, em suas relações com a coordenação de comportamento em comunidades humanas (o aspecto comunicativo da linguagem, mencionado por Peirce, Morris e BüHler e novamente por SPERBEr \& Wilson e Strohner). De acordo com esses seis autores, podemos denominar o primeiro aspecto de gramatical, o segundo de semântico e o terceiro de pragmático. 
Até hoje, existem poucas concepções lingüísticas que tratam de forma equilibrada esses três aspectos funcionais e que, por isso, podem ser consideradas pontos de partida para a formulação de uma teoria realmente compreensiva da linguagem (cf. BLÜHDORN 1993 b). As abordagens estruturalistas clássicas concentraram-se completamente no aspecto estrutural, desconsiderando os aspectos da cognição e da comunicação. As concepções pragmáticas dos anos setenta, especialmente da assim chamada análise do enunciado e da análise da conversação, muitas vezes só consideraram o aspecto comunicativo, deixando de fora a estrutura formal e a cognição. As abordagens funcionalistas clássicas discutiram a estrutura formal e a comunicação, mas não a cognição. Os gerativistas estudam a estrutura formal e a cognição, desconsiderando a comunicação. E muitos cognitivistas examinam a cognição e a comunicação, esquecendo-se, por enquanto, do aspecto estrutural. Mesmo assim, a lingüística do fim do nosso século parece estar se aproximando, finalmente, da arquitetura que em termos teóricos já foi concebida pelos semioticistas de seu início.

\section{DELIMITAÇÃO SISTEMÁTICA}

\subsection{Bühler e Jakobson}

Na segunda parte deste artigo, pretendo apresentar um modelo sistemático do objeto da lingüística, buscando uma delimitação mais precisa de suas três subdisciplinas. Para tanto, comecemos novamente com BüHLER (1934-1982).

O ponto fraco do modelo organon se encontra na sua centralização total ao redor do signo, desconsiderando completamente as funções dos outros participantes da comunicação, a saber, do emissor, do receptor e dos objetos e estados de coisas comunicados. As conseqüências dessa deficiência mostram-se de uma maneira especial-mente clara na concepção da função apelatória. Segundo BüHLER, a orientação do comportamento do receptor pelo signo se dá na forma de instruções e pedidos que exigem determinadas reações, como, por exemplo, a 
solicitação de fechar a porta, à qual o receptor reage fechando a porta. Tais instruções, porém, não são contribuições do signo, e sim, do falante. É o falante que convida seu interlocutor a fechar a porta e, assim, persegue seus interesses na interação.

Mas o signo também tem a força de orientar o receptor, e apenas esta força deveria ser entendida como sua função apelatória. Cada texto pode ser visto como um conjunto de instruções para realizar um comportamento psíquico que leva à formação de determinados pensamentos e, finalmente, à compreensão daquilo que o falante quer comunicar (cf. WeInRICH 1993: 18). Cada elemento do texto, então, seria uma instrução parcial deste conjunto. Tal aspecto proce-dural embutido no signo lingüístico, que podemos até chamar de sua força auto-explicativa, realmente merece a denominação de função apelatória.

A centralização do modelo de BüHLER em volta do signo levou muitos autores a interpretá-lo como um modelo estilístico. O mais conhecido destes autores é Roman JaKOBSon (1896-1982). JaKOBSON, em seu célebre artigo Linguistics and poetics de 1960, distingue seis funções que chama de emotiva, conativa, referencial, fática, metalingual $^{1}$ e poética. Estas funções, o próprio JaKOBSON apresenta como funções da linguagem, referindo-se a BüHLER, mas o contexto de seu artigo demonstra indubitavelmente que, na verdade, ele está pesquisando funções de textos, ou seja, características estilísticas, entre as quais a que mais lhe interessa é a qualidade poética.

A confusão de funções da linguagem com funções de textos tornou-se, desde então, uma tradição verdadeiramente lamentável na lingüística funcional (cf. BLÜHDORN 1993 a: 20 ss.). A meu ver, ela só pode ser quebrada quando se concebe um modelo organon completo, ou seja, um modelo que inclua as funções do emissor, do receptor e da mensagem, além das funções do signo.

\subsection{Comunicação}

O método de BüHLER, ao determinar as funções do signo, consistiu de três passos: primeiro, estabeleceu um modelo de uma 
situação prototípica de comunicação, reunindo os quatro participantes indispensáveis, o falante, o receptor, a mensagem e o signo; segundo, descreveu a constelação entre esses quatro participantes como um conjunto de relações binárias, ou seja, três relações entre o signo e cada um dos outros participantes; e terceiro, interpretou tais relações como funções do signo.

Podemos aplicar a mesma técnica para determinar as funções dos outros três participantes. A situação prototípica de comunicação pode ser visualizada da seguinte maneira (cf. BLÜHDORN 1993 a:15 ss.):

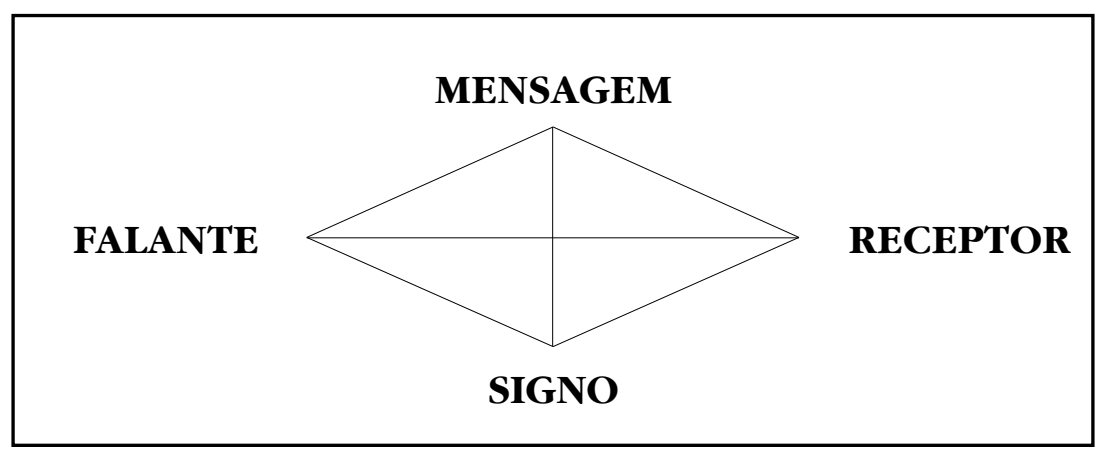

FIGURA 2: Modelo da situação prototípica de comunicação

A partir da análise das relações entre cada dois dos participantes, chegamos a três funções do falante, três do receptor e três da mensagem (cf. ib.: 41 s.).

O falante, em relação ao signo, tem a função de emiti-lo. A emissão de signos, nesse sentido, começa com a produção cognitiva e termina com um processo material e mecânico. A produção cognitiva não é acessível à observação e, portanto, não pode ser concebida de uma maneira satisfatória à base de considerações meramente pragmáticas. Voltaremos a este assunto mais tarde. Quanto aos processos mecânicos da língua falada, a fonética articulatória é a disciplina competente para tratar desse assunto. Mesmo sendo relativamente antiga e bem desenvolvida, ela foi 
excluída da lingüística estruturalista por não ser voltada a objetos abstratos (cf. Pike 1943; KoHLER 1995: 22 s.). Mas, como toda comunicação é concreta, nada impede que a fonética seja incorporada à pragmática como parte da ciência da emissão de signos. A outra parte seria, evidentemente, a grafética produtiva, a ciência da emissão de signos escritos, que, por enquanto, se encontra bem menos desenvolvida (cf. Bussmann 1990: 294).

Em relação ao destinatário, o falante tem a função de destinação, ou seja, ele precisa se posicionar corporalmente e mentalmente de uma maneira adequada, para que o destinatário possa entendêlo. Uma teoria da destinação seria uma teoria das intenções interpessoais na comunicação. Para dar uma idéia do que tal subdisciplina da pragmática deve pesquisar, podemos nos servir de uma variante do modelo de JAKOBSON (1960), já mencionado. Podemos distinguir cinco tipos de intenções que um destinador pode manter frente a um destinatário: intenções fáticas (estabelecer, manter ou terminar o contato), intenções expressivas (mostrar atitudes subjetivas), intenções conativas (influenciar as opiniões ou o comportamento do destinatário), intenções informativas (informar o destinatário sobre estados de coisas) e intenções poéticas (produzir efeitos estéticos) (cf. BlüHDORn 1997 a: 67). Em situações comunicativas naturais, normalmente realizam-se diferentes tipos de intenções paralelamente. Para poder alcançar quaisquer de suas intenções, é necessário que o falante mantenha, no decorrer da comunicação, hipóteses sobre o estado atual do conhecimento do destinatário.

Em relação à mensagem, o falante tem a função de codificá-la. Isto pressupõe que a mensagem já exista pré-fabricada em sua mente, ou seja, que o falante já saiba o que quer dizer. Sem poder aprofundar esta questão complicada no presente contexto (cf. DitTMann, Blanken \& WALLESCH 1988: 4 s.; SCHWARZ 1992 a: 166 ss.), precisamos constatar que a mensagem, no contexto pragmático, é uma grandeza fictícia. Ela é necessária para garantir a impressão mútua de entendimento entre os comunicantes, mas ela não existe como entidade física.

Quanto ao receptor, sua função em relação ao signo é a de percebê-lo e de construir um percepto cognitivo para depois 
interpretá-lo (cf. STROHNER 1990: 30 s., 85, 92 ss.). Encontramos aqui o lugar da fonética auditiva e da grafética perceptiva. Os processos da interpretação, bem como os da produção, não podem ser descritos adequadamente dentro do âmbito da pragmática.

Em relação ao falante, o receptor tem a função de ajustar-se. Ajustar-se significa concentrar a atenção na fonte de signos, assim gerando a disposição para perceber e compreender (cf. BLÜHDORN 1993 a: 36). Tal comportamento parece oferecer menor variação de possibilidades do que a destinação. Todavia, a psicologia e a psicolin-güística da recepção já mostraram claramente que se trata de um processo altamente ativo e não, como as teorias mais antigas ensi-navam, passivo e automático (cf. SchNotz 1994). Entre outros, o receptor, tal como o falante, precisa manter, durante a comunicação, hipóteses sobre o estado atual do conhecimento de seu parceiro.

Em relação à mensagem, o receptor tem a função de decodificá-la, ou seja, de construir em sua mente uma representação daquilo que o falante, provavelmente, quer comunicar. É preciso repetir que, em termos pragmáticos, tal representação não chega a ser observável, ou seja, a mensagem como participante da comunicação permanece fictícia.

As funções do signo - expressão, apelo e representação - já foram mencionadas. Cabe advertir mais uma vez que elas não podem ser confundidas com as intenções do destinador frente ao destina-tário. Enquanto a destinação é uma relação interpessoal regida por vontade, as funções do signo são totalmente independentes das intenções do produtor. Assim, por exemplo, o falante pode ter a intenção expressiva de mostrar seu bom humor, e o signo produzido expressa apenas que está bêbado.

Quanto às funções da mensagem, estas são tão fictícias como a própria mensagem. Mesmo assim, porém, elas são necessárias para manter em funcionamento a comunicação. Em relação ao falante, a mensagem tem a função de estimulá-lo a produzir signos; em relação ao receptor, ela tem a função de constituir o problema a ser resolvido através de um esforço cognitivo; e em relação ao signo, a mensagem constitui seu significado. 
Todas essas funções seriam funções comunicativas e, portanto, objetos a serem pesquisados pela pragmática. Quanto às relações entre o falante e o receptor, a visão é convencional, mesmo usando os termos não-convencionais destinação e ajustamento. Quanto à emissão e à percepção, a inclusão da fonética e grafética na pragmática já foge do conceito tradicional desta subdisciplina. Quanto às funções do signo, especialmente a relação com a mensagem (ou seja, a representação) nunca foi considerada objeto da pragmática, e sim, da semântica (cf. p.ex. Polenz 1985: 101 ss.). Também as funções da própria mensagem, na visão convencional, deveriam ser concebidas como objetos da semântica.

Segundo este modelo, portanto, a pragmática é bem mais abrangente do que comumente se supõe. Pode-se argumentar inclusive que, além de incorporar vários aspectos de caráter semântico, ela inclui também aspectos gramaticais junto às funções de codificação e decodificação, emissão e recepção. Dessa maneira, a pragmática se apresenta como uma subdisciplina da lingüística, na qual as outras subdisciplinas se inserem, e não vice-versa. Mesmo assim, a pragmática continua subdisciplina e não pode ser entendida como a lingüística inteira, pois em várias questões depende do aprofundamento que só pode ser garantido pela semântica e pela gramática. $\mathrm{Na}$ verdade, há muitos assuntos sobre os quais a pragmática tem pouco a dizer a não ser trivialidades.

\subsection{Cognição}

Como se define, então, o objeto da semântica? Observamos que a constelação prototípica da situação comunicativa envolve dois organismos humanos como participantes, o falante e o receptor. Os dois, durante a comunicação, precisam processar dados em suas mentes: o falante, para traduzir a representação interna da mensagem em signos externos, e o receptor, para traduzir signos externos numa representação interna.

Podemos modelar os processos cognitivos aí envolvidos como uma constelação de três participantes: um organismo humano como 
integrante de uma comunidade, um conceito como integrante de uma realidade e um signo como integrante de um código (no caso, um código lingüístico) (cf. BLÜHDORN 1993 a: 25 ss.): ${ }^{2}$

\section{CÓDIGo}

SIGNO

\section{ORGANISMO}

COMUNIDADE
CONCEITO

REALIDADE

FIGURA 3: Modelo prototípico dos processos cognitivos envolvidos na comunicação

Novamente, examinaremos as relações que cada participante mantém com cada um dos outros.

O organismo como integrante de sua comunidade funciona, tanto em relação ao conceito quanto ao signo, como produtor e como usuário. Em relação ao conceito, criando-o, ele se apropria do mundo externo, ou seja, gera uma imagem interna que para ele representa o mundo e seus componentes. A imagem inteira do mundo chamamos de realidade, enquanto uma imagem de um determinado objeto ou estado de coisas seria um conceito (cf. BlüHDorn 1997 b). Cada organismo mantém um estoque de conceitos pré-fabricados em sua memória. Ao gerar novos conceitos - mensagens a serem comunicadas, por exemplo - ele ativa componentes já disponíveis na memória, combina-os e os manipula.

Em relação ao signo, criando-o, ele produz um meio para poder se comunicar. Cada organismo humano mantém um estoque de signos pré-fabricados em sua memória, cujo sistema é chamado de 
código. Utilizando os elementos do código, o organismo pode seguir dois caminhos diferentes, um de produtor, o outro de receptor. Como produtor, ele cria novos signos a partir de elementos já dispo-níveis, sendo orientado pelos conceitos da mensagem que tem em mente. Como receptor, ele cria novos conceitos a partir dos compo-nentes de sua memória, sendo instruído pelos signos.

O conceito como integrante de uma realidade representa, para o organismo, um componente do mundo. Podemos distinguir dois tipos de conceitos: os objetos (Gegenstände) e os estados de coisas (Sachverhalte). Por estados de coisas entendemos constelações de objetos, por exemplo, uma situação de comunicação. Os conceitos armazenados na memória devem, em parte, ser protótipos, como o modelo da situação prototípica de comunicação. Assim, eles servem para padronizar a interação entre o organismo e seu meio ambiente.

Quanto à sua relação com o signo, os conceitos o motivam. A lingüística, sob a influência do estruturalismo, baseou-se, durante muito tempo, no conceito saussuriano do signo, o qual é um conceito diádico, havendo entre seus dois componentes - significante e significado - uma relação arbitrária (cf. SAussure 1916: 79 ss.). Neste modelo, não existe motivação do signo pelo conceito. Contudo, o modelo de SAussure foi um modelo voltado à palavra. Desde que a oração e, finalmente, o texto, passaram a ser entendidos como as unidades básicas da linguagem, o postulado da arbitrariedade perdeu muito de sua força convencedora. ${ }^{3}$ Hoje, um número crescente de lingüistas se interessa pelos aspectos icônicos da relação entre signo e conceito (cf. p. ex. LeIss 1992: 5). Um exemplo seria a estrutura cronológica de uma narrativa, que retrata a seqüência dos eventos narrados. Nesse sentido, os conceitos motivam os signos.

Finalmente, o signo como integrante de um código tem a função de orientar e socializar o organismo e de estruturar a realidade. No código armazenado na memória do organismo, podemos distinguir quatro tipos de conhecimento lingüístico: o conhecimento formal, que coordena a geração de representações fonológicas e grafêmicas; o conhecimento combinatório, que coordena a geração 
de estruturas sintáticas; o conhecimento denotativo, que coordena as ligações entre signos e conceitos; e o conhecimento estratégico, que coordena as ligações entre signos e estratégias de destinação (cf. BLÜHDORN 1995: 99 ss.). Esse conhecimento deve ser compartilhado em grande parte pelos integrantes de uma comunidade, e a própria existência da comunidade se dá em função do conhecimento lingüístico compartilhado. Nesse sentido, o signo socializa o organismo e o orienta quanto ao seu comportamento comunicativo.

Em relação à realidade, o signo tem a função de estruturá-la. No código lingüístico sedimentam-se as categorias e os padrões de situações com cuja ajuda os integrantes de uma comunidade organizam sua vida. Assim, o conhecimento do mundo já vem embutido na língua e, ao aprender sua língua materna, as crianças recebem a estrutura da realidade prevista por sua comunidade.

Todos estes aspectos dizem respeito a funções cognitivas e, portanto, fazem parte do objeto da semântica em nosso modelo. Verificamos que nossa concepção, como no caso da pragmática, prevê um âmbito bem mais abrangente do que as concepções convencionais. Por um lado, incluímos uma série de aspectos que tradicionalmente seriam tratados pela retórica, pela teoria literária, pela sociolingüística e pela psicologia; por outro lado, incluímos aspectos gramaticais como as informações formais e combinatórias dentro do código. Na verdade, a semântica é concebida como uma subdisciplina da lingüística, na qual a gramática se insere, e não viceversa. Mas, como no caso da pragmática, isto não significa que a semântica pode dispensar a gramática. Muito pelo contrário, em várias questões, ela depende do aprofundamento que só a gramática pode garantir. Também no caso da semântica, há muitos assuntos sobre os quais ela tem pouco a dizer a não ser trivialidades.

\subsection{Estrutura formal}

O que é, então, o objeto da gramática? No âmbito da semântica, apresentamos o signo lingüístico como integrante de um código. O signo em si foi concebido como um texto que se compõe de orações 
as quais se compõem de palavras, sendo as orações e as palavras também signos. O signo, então, existe em dois contextos: um contexto sintagmático numa cadeia de signos e um contexto paradigmático numa classe de signos. Isto já foi ensinado por Saussure, Hjelmslev, JAKOBSOn e outros estruturalistas (cf. NÖTH 1996, JAKOBSON 1956).

A constelação funcional pode ser visualizada com facilidade:

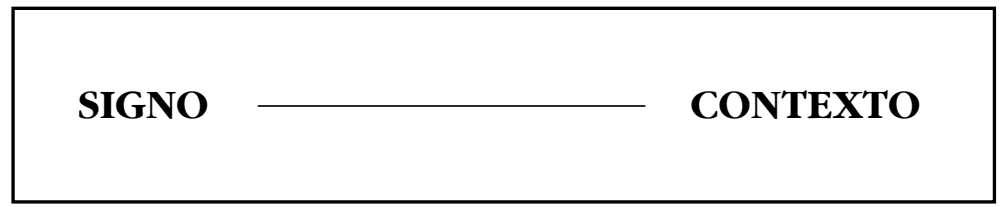

FIGURA 4: Modelo prototípico das relações formais dos signos

Temos, aqui, apenas uma função do signo em relação ao contexto e uma função do contexto em relação ao signo. As duas funções são divididas em funções parciais, conforme seja o contexto concebido como cadeia, ou como classe.

O signo funciona, em relação à cadeia de signos, como elemento contíguo. Nesta função, ele pode condicionar a presença de outros signos (como acontece no caso das combinações fonológicas e grafêmicas, da concordância morfológica e da regência verbal) ou pode preencher as condições estabelecidas por outros signos. Em relação à classe, o signo funciona como elemento semelhante a outros signos. Esta função concretiza-se, como a outra, em todos os níveis de complexidade estrutural desde o fonema até o tipo de texto. O que pertence à mesma classe, o que é semelhante, pode (salvo restrições particulares) ser substituído.

O contexto funciona, em relação ao signo, como o ambiente que o delimita. Na cadeia, o signo é delimitado como segmento. Essa delimitação garante que pode ser substituído. Na classe, o signo é delimitado como exemplar. Essa delimitação garante que pode ser concatenado.

Esses poucos aspectos que, todavia, têm um grande campo de aplicação, formam, segundo nosso modelo, o âmbito legítimo da 
gramática. Assim concebida, a gramática aproxima-se muito dos modelos estruturalistas radicais. Ela é vista como uma subdisciplina da lingüística que se interessa apenas por estruturas abstratas e formais e não considera nem significados, nem comunicação. Diferentemente da arquitetura da lingüística estruturalista, no entanto, tal gramática não forma o fundamento, mas sim, o núcleo da lingüística. Para que ela não perca o contato com a realidade cotidiana, está inserida na semântica, e, junto com ela, na pragmática e fica restringida aos objetos verdadeiramente abstratos, ou seja, objetos que não têm significado algum.

\subsection{Pragmática, semântica e gramática}

A arquitetura da lingüística e de seus objetos pode, então, ser ilustrada da seguinte maneira:

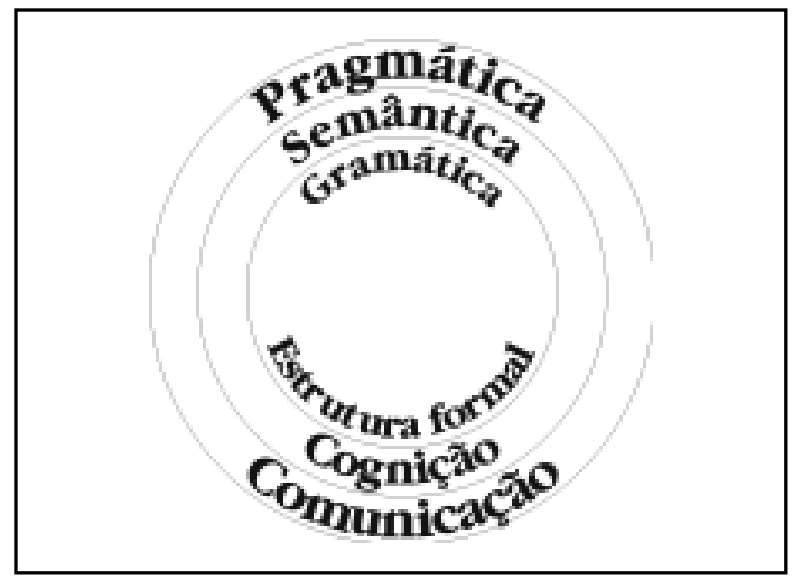

FIGURA 5: A relação entre pragmática, semântica e gramática como subdisciplinas da lingüística

Ao se aproximar de seu objeto, o lingüista tem duas opções. Por um lado, pode começar com a análise das regras estruturais, examinando as precondições que elas estabelecem para a cognição e a comunicação, continuar com a investigação das precondições 
que a cognição estabelece para a comunicação e terminar com a análise da comunicação. Por outro lado, ele pode seguir o caminho inverso: começar com a análise da comunicação, pesquisando quais das suas exigências devem ser preenchidas por contribuições da cognição e da estrutura formal dos signos, continuar perguntando quais exigências da cognição devem ser preenchidas por contribuições da estrutura formal e terminar com a análise das regras estruturais. O primeiro caminho será denominado o método estrutural, o segundo, o método funcional. A decisão sobre qual caminho é mais vantajoso só pode ser tomada de acordo com o objeto específico pesquisado.

\subsection{Fenômenos lingüísticos}

Para terminar esta parte do artigo, gostaria de apresentar uma tipologia de fenômenos lingüísticos segundo as subdisciplinas pelas quais eles devem ser pesquisados.

Quem optar pelo caminho funcional, encontrará, primeiramente, questões que pertencem à comunicação, mas não à cognição e nem à estrutura formal dos signos, como, por exemplo, a emissão, transmissão e imissão de sinais físicos. Para a descrição funcional de tais objetos, os termos da pragmática são necessários e suficientes. Em segundo lugar, encontrará questões que pertencem à comunicação e à cognição, mas não à estrutura formal, como, por exemplo, a geração de uma estratégia argumentativa a ser perseguida durante uma conversa. Para a descrição de tais objetos, os termos da pragmática e da semântica, mas não da gramática, são necessários e suficientes. Em terceiro, encontrará questões que pertencem à comunicação, cognição e à estrutura formal, como, por exemplo, a produção de textos. Para a descrição de tais objetos, os termos da pragmática, da semântica e da gramática são necessários.

Quem optar pelo caminho estrutural, encontrará primeira-mente questões para cuja descrição os termos da gramática são necessários e suficientes, como, por exemplo, em alemão ou latim, o campo da 
declinação. Em segundo lugar, encontrará questões, para cuja descrição estrutural os termos da gramática e da semântica, mas não da pragmática, são necessários e suficientes, como, por exemplo, no alemão e no português, a valência dos verbos. Em terceiro, encontrará questões para cuja descrição os termos da gramática e da pragmática, mas não da semântica, são necessários e suficientes, como, por exemplo, a transformação de representações fonológicas e grafêmicas em sinais fônicos e gráficos, respectivamente. Em quarto lugar, finalmente, encontrará questões para cuja descrição os termos da gramática, da semântica e da pragmática são necessários, como, por exemplo, no alemão e no português, o campo da dêixis.

É interessante que, em nenhum dos dois caminhos, o pesquisador encontrará questões, para cuja descrição os termos da semântica sozinhos seriam suficientes. Isso acontece devido ao fato de que a cognição não se manifesta diretamente no mundo externo. A comunicação manifesta-se imediatamente no comportamento dos organismos e, portanto, pode ser pesquisada com relativa facilidade. A estrutura formal dos signos não se manifesta, mas pode ser pesquisada a partir de material físico, ou seja, de signos fônicos e gráficos. O acesso a questões semânticas só se abre ou através da gramática, ou através da pragmática. Isso aponta para uma certa dependência da semântica como subdisciplina da lingüística, ou, como disse Monika Schwarz, para sua função de vínculo.

\section{DIVISÃO DE TRABALHO}

\subsection{Valência verbal}

$\mathrm{Na}$ terceira parte deste artigo, quero discutir a divisão de trabalho entre pragmática, semântica e gramática a partir de um exemplo concreto, a saber, a partir da valência dos verbos. No último parágrafo, ela foi mencionada como um objeto para cuja descrição os termos da gramática e da semântica, mas não da pragmática, são necessários e suficientes. 
Uma das questões mais discutidas na teoria das valências é a discriminação entre o que Borba (1996: 20 ss.) denomina de argumentos (sujeitos e objetos/complementos) e participantes (especificadores, adjuntos e circunstantes). Na tradição terminológica alemã e anglo-americana, a distinção é feita entre complementos (em alemão, Ergänzungen) e adjuntos (em alemão, Angaben) (cf. p. ex. Welke 1988: 21 ss.). No início da discussão sobre esse assunto, nos anos cinqüenta e sessenta, pensava-se, em consonância com a gramática tradicional, numa oposição principalmente gramatical (cf. Tesnière 1959; Helbig 1965, 1966). No final dos anos sessenta e no início dos anos setenta, um número cada vez maior de pesquisadores introduziu argumentos semânticos na discussão, postulando, sob a influência da teoria dos casos (Fillmore 1968, entre outros), uma valência semântica distinta da valência sintática (p. ex. HelBig 1979; SEYFERT 1979: 289 ss.) ou até tomando uma valência lógico-semântica como ponto de partida (cf. Bondzio 1969). No final dos anos setenta, entraram na pauta, ainda, considerações comunicativas (p. ex. BuuHM 1978) que levaram conseqüentemente ao postulado de uma valência pragmática (cf. Ruzicka 1978; HelBig 1985).

A questão da valência tornou-se, assim, um campo para o qual reivindicaram sua competência tanto a gramática, quanto a semântica e a pragmática. Mas a colaboração das três, por enquanto, não levou a um esclarecimento das questões polêmicas. Pelo contrário, algumas dúvidas tanto se agravaram, que um número crescente de lingüistas está disposto a abandonar a teoria das valências. O meu argumento será que uma parte das aporias encontradas surgiu justamente por falta da devida divisão de trabalho entre as subdisciplinas da lingüística.

\subsection{Omissibilidade}

O primeiro critério utilizado para distinguir entre complementos e adjuntos foi o critério da omissibilidade (em alemão, Weglaßbarkeit) (cf. Helbig \& Schenkel 1973: 33; Helbig 1992: 85). 
Segundo este critério, complementos seriam obrigatórios, enquanto adjuntos seriam passíveis de omissão:

(1.a) De madrugada, Dalva deu um osso ao cachorro.

Neste exemplo, o elemento de madrugada pode ser omitido sem alterar a gramaticalidade da sentença enquanto que a omissão tanto de um osso quanto de ao cachorro tornaria a oração nãogramatical:

(1.b) Dalva deu um osso ao cachorro.

(1.c) *De madrugada, Dalva deu ao cachorro.

(1.d) *De madrugada, Dalva deu um osso.

O critério da omissibilidade cria, no entanto, classes bastante heterogêneas. Por um lado, os elementos tipicamente não-omissíveis são os sujeitos e objetos da gramática tradicional. Mas alguns objetos podem ser omitidos, como por exemplo o objeto direto junto ao verbo comer.

(2.a) Dalva comeu uma maçã.

(2.b) Dalva comeu.

Além disso, em português, como em todas as línguas com a assim chamada qualidade de pro-drop (cf. Сномsку 1981-1993: 240 ss.; Negrão \& MÜller 1996), sujeitos também podem ser omitidos:

(2.c) E bebeu também.

Por outro lado, os elementos tipicamente omissíveis são as especificações adverbiais da gramática tradicional. Alguns elementos adverbiais, porém, dão a impressão de serem não-omissíveis:

(3.a) Dalva mora nos fundos da casa.

(3.b) *Dalva mora.

Vários autores contam tais elementos como complementos (cf. Helbig \& Schenkel 1973: 34), enquanto outros os consideram adjuntos obrigatórios (cf. WeLKe 1988: 45 ss.). 
A partir desse ponto foi questionado o próprio conceito da omissibilidade. No início da discussão, muitos lingüistas acharam que se tratasse de um conceito gramatical, pois a omissão de um elemento obrigatório parece deixar uma oração gramaticalmente incorreta. Outros chegaram - justamente à base de sentenças como (3.a) - à conclusão de que dependeria a omissibilidade mais do contexto comunicativo e fosse, portanto, uma questão pragmática (cf. BLÜHDORN 1993 a: 48 ss., 106 ss.):

(3.c) A - A Dalva mora nos fundos da casa, não é? B - Mora.

Nesta variante, o falante $\mathrm{B}$ responde à pergunta de $\mathrm{A}$ com uma oração evidentemente correta, com o verbo morar sem complemento algum. Uma explicação seria que a omissibilidade de elementos tenha a ver com as hipóteses que o falante mantém sobre o estado atual do conhecimento do destinatário, sendo que ele omite de preferência aquilo que o destinatário já deve saber ou o que não interessa para seus fins comunicativos (cf. BLÜHDORN 1993 a: 107 s.).

Sob este ponto de vista, a principal crítica ao critério da omissibilidade, tal como ele foi utilizado pelos partidários de uma visão gramatical da valência, alega que a omissão de elementos sempre foi testada em orações descontextualizadas e nunca em contextos pragmaticamente adequados, deixando aparecer muitos elementos obrigatórios, que poderiam, em determinados contextos, ser dispensados (cf. p. ex. Bluhm 1978). Em conseqüência, a omissibilidade foi descartada como critério decisivo para a distinção entre complementos e adjuntos.

\subsection{Obrigatoriedade conceitual}

O segundo critério discutido foi o da obrigatoriedade conceitual (em alemão, Sinnotwendigkeit) (cf. Helbig 1965: 325; Welke 1988: 37 ss.). Segundo este critério semântico, os complementos seriam conceitualmente obrigatórios, enquanto os adjuntos seriam 
conceitualmente dispensáveis. No caso de comer, por exemplo, não é possível imaginar uma situação em que alguém come sem comer algo. Assim, mesmo quando não se menciona o objeto, ele seria conceitualmente obrigatório.

Este critério resolve o problema dos sujeitos e objetos omissíveis, mas gera, em compensação, uma outra aporia que tem a ver com as especificações de lugar e, particularmente, de tempo. Tais especificações - circunstantes, na terminologia de BorBA (1996: 22) - são unanimemente consideradas adjuntos, pois acrescentam-se e omitem-se de uma maneira relativamente livre em quase toda oração.

Mas se não é possível imaginar alguém comendo sem comer algo, como é possível imaginar alguém comendo sem comer num determinado tempo e lugar? Para os seres humanos, todos os estados de coisas necessariamente se inserem nas dimensões de tempo e espaço, mesmo os que parecem genéricos, pelo simples motivo de que os seres humanos dependem fundamentalmente de tempo e espaço e experimentam diariamente seus limites nessas dimensões. Assim, uma especificação de tempo e espaço pode e deve ser considerada com qualquer estado de coisas. Na verdade, encontramos justamente neste fato o motivo pelo qual tais especificações podem ser livremente acrescentadas e omitidas. Os limites de tempo e espaço são tão óbvios e ubiqüitários, que a cada momento estamos preparados para uma restrição temporal ou espacial.

Em outras palavras, especificações de tempo e lugar, como alguns objetos e sujeitos, são omissíveis, mas conceitualmente obrigatórios. Portanto, deveriam ser considerados complementos. Isto, evidentemente, acabaria com a distinção entre complementos e adjuntos, pois a categoria dos adjuntos se esvaziaria. Logo, o critério da obrigatoriedade conceitual também deve ser descartado.

\subsection{Classe do sintagma}

Um terceiro critério já conhecido a partir da gramática tradicional é o da classe do sintagma (em alemão, Ausdrucksklasse) (cf. Helbig 1992: 73; Nicola \& Infante 1993: 260 ss., 281 s.; SaCConi 
1994: 309 ss., 321 ss.). Segundo este critério, que é um critério gramatical, os complementos seriam sintagmas nominais, enquanto os adjuntos seriam sintagmas adverbiais (cf. VATER 1978).

No entanto, existem sintagmas nominais de uma mesma forma, mas de funções muito diferentes:

(4.a) Dalva agendou o dia todo.

(4.b) Dalva dormiu o dia todo.

Em (4.a), o elemento o dia todo tem uma função análoga à de uma maçã em (2.a). Conseqüentemente, é objeto direto. Em (4.b), no entanto, o dia todo tem uma função análoga à de de madrugada em (1.a). Conseqüentemente é especificação de tempo. No alemão, que distingue quatro casos dos sintagmas nominais (nominativo, acusativo, dativo e genitivo), pode-se mostrar que todos eles têm um uso paralelo a (4.a), em que o elemento sugere uma interpretação como complemento, e um outro uso, paralelo a (4.b), em que o elemento se presta mais a uma interpretação como adjunto (cf. BlÜHDORN 1993 a: 99 ss.).

Na parte dos sintagmas adverbiais, o que causa equívocos são os verbos de extensão, movimento, transporte, etc.:

(5) A conferência durou das duas às quatro horas.

(6) O deserto estende-se até o litoral.

(7) Dalva foi ao cinema.

Muitos lingüistas tiveram a intuição de que sintagmas adverbiais do tipo dos grifados se ligassem de uma maneira semanticamente mais íntima com os seus verbos do que as especificações ordinárias de tempo e espaço. Como eles às vezes também são de difícil omissão, foram freqüentemente considerados complementos (p.ex. HeLBIG \& SCHENKel 1973; Borba 1996).

Assim, o critério da classe do sintagma também não leva a uma distinção consistente entre complementos e adjuntos e, por conseguinte, também foi descartado (cf. Helbig 1992: 74). 


\subsection{Regência verbal}

Um quarto critério, novamente de natureza gramatical e já conhecido a partir da gramática tradicional, é o da assim chamada regência verbal (em alemão, Verbrektion) (cf. FERNANDEs 1991; BORBA et al. 1991). Segundo este critério, os complementos recebem sua característica gramatical (caso ou preposição) do verbo, enquanto os adjuntos ou não têm característica gramatical (no caso de sintagmas adverbiais) ou não a recebem do verbo (no caso de sintagmas nominais).

Assim, em português, o objeto direto deve ser um sintagma nominal sem preposição e o objeto indireto, um sintagma nominal preposicionado com a preposição determinada pelo verbo. Quanto ao sujeito, há autores que acham que ele não é regido pelo verbo (p. ex. Borba 1996: 13) e outros que o consideram regido (p. ex. ENGEL 1994: 90 ss.). Se definimos regência como a determinação da forma gramatical do elemento regido pelo elemento regente, podemos conceber a concordância entre sujeito e verbo como reflexo desta relação. Em outras palavras: enquanto o objeto direto deve ser realizado como um sintagma nominal não-preposicionado sem concordância, o sujeito deve ser realizado como um sintagma nominal não-preposicionado com concordância. Essa concepção não levaria necessariamente a uma identificação simplificadora entre concordância e regência. A regência em si consistiria do mero fato de que o verbo exige a concordância no caso do sujeito e não a permite no caso do objeto. A forma concreta que a concordância assume, pode bem ser vista como resultado de um ajuste mútuo.

Enquanto o comportamento de sujeitos e objetos permite sua classificação como elementos regidos (no sentido acima definido), o comportamento de especificações de tempo, lugar, modo, causa, fim, etc. não permite tal classificação. Nestes elementos, o verbo não exerce influência alguma sobre a forma que assumem:

(8.a) Dalva dormiu três horas.

(8.b) Dalva dormiu das duas às quatro. 
(8.c) Dalva dormiu na garagem.

(8.d) Dalva dormiu aqui.

(8.e) Dalva dormiu bem.

(8.f) Dalva dormiu porque estava muito cansada.

(8.g) Dalva dormiu apesar de ter muito trabalho.

(8.h) Dalva dormiu mesmo assim.

(8.i) Dalva dormiu para esquecer a derrota.

Dessa maneira, o critério da regência, por antigo que seja, mostra-se ainda o mais consistente (cf. BLÜHDORN 1993 a: 106). A distinção entre complementos e adjuntos parece, então, uma questão meramente gramatical. A discussão sobre ela se complicou justamente porque se tentaram resolver questões gramaticais com argumentos semânticos e pragmáticos, misturando-se assim, indevidamente, as subdisciplinas da lingüística. Um princípio metodológico fundamental, especialmente enfatizado pelos adeptos de uma visão modular da cognição humana, diz que questões provenientes de uma determinada área devem ser resolvidas com os meios pertencentes a esta área, e não com os meios pertencentes a outras.

No entanto, a visão puramente gramatical da valência deixa algumas dificuldades abertas, como discutiremos em seguida.

\subsection{Preposições}

Uma questão bastante discutida é a de como se saber se uma preposição é regida pelo verbo ou não (cf. BLÜHDORN 1993 a: 103 ss.). Existem casos óbvios de preposições regidas, como:

(9) Dalva sonhou com panquecas.

e casos óbvios de preposições não-regidas, como:

(10) Dalva foi ao cinema.

Mas existem, também, muitos casos de dúvida, como:

(11.a) Dalva falou sobre metafísica. 
Foram sugeridos três critérios para delimitar, com mais clareza, os dois tipos de preposições. O primeiro critério foi o da combinabilidade (em alemão, Kombinierbarkeit). Segundo este critério, preposições que se combinam apenas com determinados verbos podem ser regidas, enquanto preposições que se combinam com quaisquer verbos não podem ser regidas (cf. HelBig 1992: 81 s.). O segundo cri-tério foi o da substitutibilidade (em alemão, Ersetzbarkeit). Segundo este critério, preposições que, junto a um determinado verbo, não podem ser substituídas por outras preposições ou outros tipos de elementos, são regidas, ao passo que preposições que, junto ao mesmo verbo, podem ser substituídas, são não-regidas (cf. ib.: 82). O terceiro critério foi o da semanticidade (em alemão, Semantizität), segundo o qual a seleção de preposições regidas independe de seu significado, enquanto a seleção de preposições não-regidas se dá em função de seu significado (cf. HelBIG \& SCHENKEL 1973: 44). Esses três critérios são aplicados em conjunto para determinar o status de uma dada preposição, ou seja, preposições que preenchem os três critérios são consideradas regidas, e preposições que preenchem menos critérios são consideradas nãoregidas (cf. BLÜHDORN 1993 a: 104). A preposição sobre no exemplo (7), portanto, é não-regida, pois preenche apenas o critério da combinabilidade. A respeito do segundo critério, ela pode ser substituída pela preposição de:

\section{(11.b) Dalva falou de metafísica.,}

e a respeito do terceiro, sua seleção depende de seu significado, pois sobre indica, numa série de contextos paralelos, sempre o assunto (observe-se, no entanto, que não é possível, em todos estes contextos, sua substituição por de):

(12.a) Dalva escreveu sobre metafísica.

(12.b) Dalva refletiu sobre metafísica.

(12.c) Dalva pesquisou sobre metafísica.

(12.d) ... um livro sobre metafísica ...

(12.e) ... uma palestra sobre metafísica ...

(12.f) ... uma discussão sobre metafísica ... 
Enquanto os critérios da combinabilidade e da substitutibilidade são de natureza gramatical, o critério da semanticidade nos coloca outra vez no âmbito da semântica. A utilização deste critério se faz necessária junto a elementos que, em termos gramaticais, podem ser considerados ou regidos ou não-regidos, sem que tenhamos meios suficientes para decidir.

$\mathrm{Na}$ verdade, este critério também é utilizado, de maneira escondida, junto à classificação dos sintagmas nominais. As preposições, em geral, servem como equivalentes de casos; por exemplo, no português, a preposição de como equivalente do genitivo e as preposições $a$ e para como equivalentes do dativo (cf. Dubois et al. 1973: 99 ss.). Os casos, por sua vez, podem ser categorias semânticas ou categorias gramaticais. Os casos semânticos (agente, paciente, beneficiário etc.) são funções padronizadas de participantes ou circunstantes de estados de coisas que facilitam o processamento cognitivo das experiências da vida e a comunicação sobre elas por meio de uma determinada estandardização (cf. p. ex. Fillmore 1968, 1977, entre outros). Os casos gramaticais (nominativo, acusativo, etc.) são formas morfológicas. Enquanto o mesmo caso semântico pode ser realizado por elementos formais distintos (p. ex. o agente em (13.a) e (13.b)), o mesmo caso gramatical pode servir como realização de diferentes casos semânticos (p. ex. o "dativo" em (14.a) e (14.b) (cf. WelKe 1988: 163 ss.):

(13.a) Dalva queimou a carta.

(13.b) A carta foi queimada por Dalva.

(14.a) Dalva deu o osso ao cachorro. (beneficiário)

(14.b) Dalva se referiu ao cachorro. (assunto)

Ora, os casos gramaticais exibem a mesma ambigüidade encontrada nas preposições quanto ao seu status como elementos regidos ou não-regidos (cf. os exemplos (4.a) e (4.b) acima). E também aqui se aplica o critério da semanticidade para distinguir entre complementos e adjuntos: nos exemplos apresentados acima, o elemento o dia todo em (4.a) é complemento porque sua qualidade 
de sintagma nominal não-preposicionado sem concordância é determinada pelo verbo, independentemente do seu significado; em (4.b), o dia todo é adjunto, porque a sua característica gramatical não é determinada pelo verbo, mas tem a função de expressar uma quantidade, como também nos exemplos seguintes (cf., sobre o acusativo de quantidade no alemão, BLüHDORN 1993 a: 101, 161):

(4.c) Dalva correu vinte quilômetros.

(4.d) Dalva engordou quatro quilos.

Esta observação indica que a distinção entre complementos e adjuntos, mesmo sendo uma distinção gramatical a princípio, não pode dispensar totalmente considerações semânticas.

\subsection{Considerações finais}

A semântica tem que ser considerada em pelo menos mais um aspecto da valência. Este aspecto foi trabalhado pela teoria dos casos e dos papéis semânticos de Fillmore (1968, 1977, entre outros), que pesquisou como se ligam as características gramaticais distribuídas pelos verbos com as características conceituais dos estados de coisas e seus participantes. Por exemplo, junto ao verbo comer, o sujeito deve ser o elemento que designa quem come, e o objeto direto deve ser o elemento que designa o que é comido, e não vice-versa, a não ser com mudança do verbo para a voz passiva (cf. também BorBA 1996: 27 ss., 49 ss.).

Sem precisarmos nos aprofundar neste campo, estamos agora na posição de resumir as nossas observações a respeito da divisão de trabalho entre gramática, semântica e pragmática no âmbito da valência verbal.

Observamos que o critério principal que decide sobre a classificação dos elementos frasais como complementos e adjuntos é o critério da regência, concretizado pelos subcritérios gramaticais da combinabilidade e da substitutibilidade e pelo subcritério semântico da semanticidade. Outro argumento semântico que entra 
na discussão das valências é a questão das ligações entre casos gramaticais e casos semânticos.

Por outro lado, foram descartados o critério gramatical da classe do sintagma e o critério semântico da obrigatoriedade conceitual, os dois por levarem a resultados inconsistentes.

Quanto ao critério da omissibilidade, mostramos que este também leva a resultados não-satisfatórios na distinção entre complementos e adjuntos. Além disso, mostramos que, no fundo, se trata de um critério pragmático que obedece a princípios pragmáticos (gerenciamento do fluxo de informações na comunicação), nada tendo a ver, portanto, com a questão da valência.

Concluímos, então, que, no campo das valências, a gramática e a semântica têm que dividir seu trabalho, cada uma voltada às ques-tões que lhe cabem, enquanto a pragmática não deve entrar no jogo.

\section{CONCLUSÃO}

Discutimos, neste artigo, as relações entre pragmática, semântica e gramática sob as perspectivas da história da lingüística, da sistemática de seus objetos e da prática do seu trabalho. Vimos que a arquitetura da lingüística foi concebida diferentemente durante a história e encontra-se hoje novamente em discussão. A visão semiótica permite uma delimitação sistemática de suas subdisciplinas que, em termos teóricos, já foi postulada no início do século XX, mas, em termos práticos, apenas começou a se concretizar no seu fim. Vimos, finalmente, que, na lingüística, quem quiser chegar a soluções convincentes e adequadas, precisa relacionar cada problema cuidadosamente com o campo de objetos ao qual pertence e tratálo com as ferramentas da subdisciplina competente. A consciência da arquitetura da lingüística é indispensável ao se decidir sobre quais tarefas assumir, quais dividir e quais seria recomendável abandonar. 


\section{NOTAS}

* Agradeço aos meus colegas Masa Nomura, Selma M. Meireles e João Azenha Junior a leitura crítica e a ajuda com a língua portuguesa e aos três pareceristas anônimos as sugetões valiosas para a elaboração da versão atual.

${ }^{1}$ Nota-se que o termo inglês metalingual function, usado por JaKOBson, foi mal traduzido para o português como função metalingüística (p.ex. em: DuBors et al. 1973: 296). Em inglês distingue-se entre metalinguistic and metalingual, sendo que o primeiro termo se refere ao discurso sobre a lingüística, enquanto o segundo se refere ao discurso sobre a língua.

${ }^{2}$ Este modelo é uma variante do modelo triádico do signo desenvolvido por Peirce (cf. Nöтн 1995: 68 ss.): o representamen peirceano corresponde ao signo, o objeto ao conceito e o interpretante ao organismo. Nota-se, porém, que o modelo de PEIRCE foi concebido como uma moldura teórica muito geral e abstrata, enquanto nossa variante aplica-se com mais facilidade à descrição concreta de processos lingüísticos. ${ }^{3} \mathrm{Na}$ verdade, o próprio SAussure, num capítulo marginal, já admitiu a possibilidade de motivação em signos compostos (cf. SAussure 1916: 152 ss.).

\section{REFERÊNCIAS BIBLIOGRÁFICAS}

ABraham, Werner. Zu John Robert Ross. Über deklarative Sätze. In: ABraham, Werner \& Robert I. Binnick (Org.). Generative Semantik. Frankfurt/Main: Athenäum, 1972, p. 279-284.

Austin, John L. How to do things with Words. Oxford: University Press, 1962.

BIERWISCH, Manfred. Semantische und konzeptuelle Repräsentation lexikalischer Einheiten. In: RuzickA, Rudolf \& Wolfgang Мотsсн (Org.). Untersuchungen zur Semantik. Berlin: Akademie, 1982, p. 61-99.

. Psychologische Aspekte der Semantik natürlicher Sprachen. In: Мотsch, Wolfgang \& Dieter Viehweger (Org.). Richtungen der modernen Semantikforschung. Berlin: Akademie, 1983a, p. 15-64.

Formal and Lexical Semantics. In: Linguistische Studien, Reihe A, 114, 1983b, p. 56-79.

Bloomfield, Leonard. Language. New York: Holt, Rinehart \& Winston, 1933.

BuÜHDORN, Hardarik. Funktionale Zeichentheorie und deskriptive Linguistik. Ein Entwurf am Beispiel des Gegenwartsdeutschen. Erlangen: Palm \& Enke, 1993a. 
BlüHDORN, Hardarik. Resenha de Monika Schwarz, Kognitive Semantiktheorie und neuropsychologische Realität. Repräsentationale und prozedurale Aspekte der semantischen Kompetenz. In: Linguistische Berichte, 146, 1993b, p. 345-347.

. Sprache und Konflikt. Einige zeichentheoretische Überlegungen zum Status rhetorischer Strategien in der politischen Kommunikation. In: ReIHER, Ruth (Org.). Sprache im Konflikt. Zur Rolle der Sprache in sozialen, politischen und militärischen Auseinandersetzungen. Berlin: de Gruyter, 1995, p. 93-112.

- Klosprüche, Graffiti, Autoaufkleber: Zur Semiotik alternativer Kommunikationsformen. In: GärTnER, Angelika (Org.). Sprache, Wortschatz, Kommunikation und Landeskunde. Beiträge zu einem Fortbildungsseminar für Deutschdozenten an brasilianischen Universitäten. São Paulo: Humanitas - FFLCH/ USP, 1997a, p. 61-71.

. Bild und Wirklichkeit. In: Zeitschrift für Semiotik, 19, 1997b (no prelo).

Bluhm, H. Über kommunikative Notwendigkeit und Valenz. In: ABrAHAm, Werner (Org.). Valence, Semantic Case and Grammatical Relations. Amsterdam: John Benjamins, 1978, p. 9-20.

Bondzio, Wilhelm. Das Wesen der Valenz und ihre Stellung im Rahmen der Satzstruktur. In: Wissenschaftliche Zeitschrift der Humboldt-Universität. Berlin, 18, 1969, p. 233-240.

Borba, Francisco da Silva et al. Dicionário gramatical de verbos do Português contemporâneo do Brasil. $2^{\text {a }}$ ed. São Paulo (UNESP), 1991.

Borba, Francisco S. Uma gramática de valências para oportuguês. São Paulo: Ática, 1996.

BüHLER, Karl. Sprachtheorie. Die Darstellungsfunktion der Sprache. Stuttgart: Gustav Fischer, 1934-1982.

Bussmann, Hadumod. Lexikon der Sprachwissenschaft. $2^{\text {a }}$ ed. Stuttgart: Kröner, 1990.

Cномкку, Noam. Aspects of the theory of syntax. Cambridge, Mass.: MIT Press, 1965. . Rules and representations. New York: Columbia University Press, 1980.

. Lectures on government and binding. The Pisa Lectures. $7^{\mathrm{a}}$ ed. Berlin: Mouton de Gruyter, 1981-1993.

Dittmann, Jürgen, Gerhard Blanken \& Claus-W. Wallesch. Einleitung: Über die Erforschung der menschlichen Sprachproduktion. In: Blanken, Gerhard, Jürgen DitTmann \& Claus-W. Wallesch (Org.). Sprachproduktionsmodelle. Neuro- und psycholinguistische Theorien der menschlichen Spracherzeugung. Freiburg: Hochschul-Verlag, 1988, p. 1-17.

Dubois, Jean et al. Dicionário de Lingüística (trad. para o português coord. por Izidoro Blikstein). São Paulo: Cultrix, 1973. 
EnGEL, Ulrich. Syntax der deutschen Gegenwartssprache. $3^{\text {a }}$ ed. Berlin: Erich Schmidt, 1994.

Fernandes, Francisco. Dicionário de verbos e regimes. $38^{a}$ ed. São Paulo: Globo, 1991.

Fillmore, Charles J. The Case for Case. In: Bach, Emmon \& Robert T. Harms (Org.). Universals in Linguistic Theory. New York: Holt, Rinehart \& Winston, 1968, p. $1-88$.

. Scenes-and-frames semantics. In: Zampolli, Antonio (Org.). Linguistic structures processing. Amsterdam: North Holland Publishing Company, 1977, p. 55-81.

Grice, H. Paul. Logic and conversation. In: Cole, Peter \& J. Morgan (Org.). Speech acts (Syntax and Semantics 3), New York: Academic Press, 1975, p. 41-58.

Helbig, Gerhard. Der Begriff der Valenz als Mittel der strukturellen Sprachbeschreibung und des Fremdsprachenunterrichts. In: Probleme der Sprachwissenschaft. Beiträge zurLinguistik. The Hague: Mouton, 1971, p. 316335.

Untersuchungen zur Valenz und Distribution deutscher Verben. In: Probleme der Sprachwissenschaft. Beiträge zur Linguistik. The Hague: Mouton, 1971, p. 336-360.

. Zum Status der Valenz und der semantischen Kasus. In: Deutsch als Fremdsprache, 16, 1979, p. 65-78.

. Valenz und Kommunikation (Ein Wort zur Diskussion). In: Deutsch als Fremdsprache, 22, 1985, p. 153-156.

. Probleme der Valenz- und Kasustheorie. Tübingen: Niemeyer, 1992.

HelBIG, Gerhard \& Wolfgang Schenkel. Wörterbuch zur Valenz und Distribution deutscher Verben. $2^{\text {a }}$ ed. Leipzig: Bibliographisches Institut, 1973.

Jakobson, Roman. Two Aspects of language and two types of aphasic disturbances. In: Jakobson, Roman. Selected Writings II. The Hague: Mouton, 1971, p. 237259 .

Jakobson, Roman. Linguistics and Poetics. In: Sebeor, Thomas A. (Org.). Style in Language. New York/London: MIT Press/John Wiley, 1960, p. 350-377.

KoHLer, Klaus J. Einführung in die Phonetik des Deutschen. $2^{\text {a }}$ ed. Berlin: Erich Schmidt, 1995.

Leech, Geoffrey N. Principles of Pragmatics. London: Longman, 1983.

LeIss, Elisabeth. Die Verbalkategorien des Deutschen. Ein Beitrag zur Theorie der sprachlichen Kategorisierung. Berlin: de Gruyter, 1992. 
Lyons, John. Semantics. Cambridge: University Press, 1977. 1981

Language and Linguistics. An Introduction. Cambridge: University Press,

Morris, Charles W. Foundations of the Theory of Signs. Chicago, Ill.: University of Chicago, 1938.

Negrão, Esmeralda Vailati \& Ana Lúcia MüLler. As mudanças no sistema pronominal do português brasileiro: Substituição ou especialização de formas? In: D.E.L.T.A., 12, № 1,1996 , p.125-152.

Nicola, José de \& Ulisses Infante. Gramática contemporânea da lingua portuguesa. $11^{a}$ ed. São Paulo: Scipione, 1993.

NöтH, Winfried. Panorama da Semiótica. De Platão a Peirce. São Paulo: Annablume, 1995.

. A Semiótica no Século XX. São Paulo: Annablume, 1996.

Oehler, Klaus. Idee und Grundriß der Peirceschen Semiotik. In: Krampen, Martin, Klaus Oehler, Roland Posner \& Thure von Uexküll (Org.). Die Welt als Zeichen. Klassiker der modernen Semiotik. Berlin: Severin \& Siedler, 1981, p. 15-49.

Peirce, Charles, S. Collected Papers (vols. 1-6 ed. por Ch. Hartshorne \& P. Weiss, vols. 7-8 ed. por A.W. Burks). Cambridge, Mass.: Harvard University Press, 19311958.

. Phänomen und Logik der Zeichen (Syllabus of Certain Topics of Logic; ed. e trad. para o alemão por H. Pape). Frankfurt/Main: Suhrkamp, 1983.

Perini, Mário A. Gramática descritiva do português. 2a ed. São Paulo: Ática, 1996.

Pike, Kenneth L. Phonetics. Ann Arbor. Mich.: University of Michigan Press, 1943.

Polenz, Peter von. Deutsche Satzsemantik. Grundbegriffe des Zwischen-den-ZeilenLesens. Berlin: de Gruyter, 1985.

Ross, John R. On declarative sentences. In: JacoBs, Roderick A. \& Peter S. RosEnBAum (Org.). Readings in English Transformational Grammar. Waltham, Mass.: Ginn \& Co., 1970, p. 222-272.

Ruzicka, Rudolf. Three aspects of valence. In: AвraнAm, Werner (Org.). Valence, semantic case and grammatical relations. Amsterdam: John Benjamins, 1978, p. 47-53.

SACCONI, Luiz Antonio. Nossa gramática. Teoria e prática. 19ª ed. São Paulo: Atual, 1994.

SADOCK, Jerrold M. Hypersentences. Urbana, III, 1969.

SAussure, Ferdinand de. Curso de Lingüistica Geral(Org. por Ch. Bally \& A. Sechehaye, ed. por I.N. Salum, trad. para o português por A. Chelini, J.P. Paes \& I. Blikstein). São Paulo: Cultrix, 1969. 
Schnotz, Wolfgang. Aufbau von Wissensstrukturen. Untersuchungen zur Kohärenzbildung beim Wissenserwerb mit Texten. Weinheim: Beltz, PsychologieVerlags-Union, 1994.

Schwarz, Monika. Einfübrung in die Kognitive Linguistik. Tübingen: Francke, 1992a. ScHWARz, Monika. Kognitive Semantiktheorie und neuropsychologische Realität. Repräsentationale und prozedurale Aspekte der semantischen Kompetenz. Tübingen: Niemeyer, 1992b.

Searle, John R. Speech acts. Cambridge: University Press, 1969.

SEYFERT, Gernot. Zur Theorie der Verbgrammatik. Tübingen: Narr, 1979.

Sperber, Dan \& Deirdre Wilson. Relevance. Communication and Cognition. Oxford: Basil Blackwell, 1986.

STrohner, Hans. Textverstehen. Kognitive und kommunikative Grundlagen der Sprachverarbeitung. Opladen: Westdeutscher Verlag, 1990.

TeSnière, Lucien. Éléments de syntaxe structurale. Paris: Klincksieck, 1959.

VATER, Heinz. On the possibility of distinguishing between complements and adjuncts. In: AвRAнам, Werner (Org.). Valence, Semantic Case and Grammatical Relations. Amsterdam: John Benjamins, 1978, p. 21-45.

Weinrich, Harald. Textgrammatik der deutschen Sprache. Mannheim: Bibliographisches Institut, 1993.

Welke, Klaus M. Einfübrung in die Valenz- und Kasustheorie. Leipzig: Bibliographisches Institut, 1998.

Wunderlich, Dieter. Pragmatik, Sprechsituation, Deixis. In: ABrAHAM, Werner \& Robert I. BinNick (Org.). Generative Semantik. Frankfurt/Main: Athenäum, 1972, p. 285313. 